\title{
Phenotypic assessment of pear varieties in mutual pollination
}

\author{
Nina Mozhar \\ Federal State Budget Scientific Institution «North Caucasian Federal Scientific Center of \\ Horticulture, Viticulture, Wine-making», 39 str. 40 Let Pobedy, Krasnodar, 350901, Russia
}

\begin{abstract}
The self-fertility and cross-fertility of pear varieties have been studied in the conditions of the of the Krasnodar region. It was established that most of the not varieties are self-fertile. The varieties are distinguished: Ladozhskaya, Malyshka and Talgar beauty, with partial self-fertility, in which a low percentage of fruit set and its fluctuation over the years are noted. Based on the pollination performed and the analysis carried out, good and acceptable pollinators for promising pear varieties were selected. It has been established that in order to form full-fledged seeds in the fruit of the pear, a full cross-pollination with good pollinators is necessary. The possibilities of individual varieties (a high percentage of fruit tying) with mutual pollination are presented. The analysis of the negative influence of technogenic factors during flowering on the inter-pollination of varieties has been carried out. Cross-pollinated varieties have a narrow selective ability to pollinate varieties, which varies over the years and depends on the growing conditions. Proved the need, when laying gardens correctly choose varieties-pollinators in order to increase the yield of varieties. According to the research results, a self-fertile variety Iyulskaya early was identified. The best pollinators were selected for promising pear varieties for the conditions of the Kuban.
\end{abstract}

The variety is one of the most important elements of the fruit production technology, which ensures the receipt of the largest amount of high-quality products $[1,2]$. The volume and stability of agricultural production is determined by the yield of agricultural crops, but often the quantity and quality of the products obtained decreases with a lack of pollinators [3]. Therefore, all varieties must be adapted to local conditions and it is important, when laying new pear orchards, to know the possibilities of varieties for inter-pollination. Mutual pollination of varieties is determined by varietal characteristics and weather conditions of the year. Under favorable flowering conditions, the degree of pollen fertility increases, the conditions for pollination and fertilization conditions improve, which leads to good fruit setting, especially in the variants of cross and free pollination [4-6]. There are a large number of cultivars that require a pollinator, but there are also self-fertile cultivars [7-9]. Self-fertility is a valuable biological and economic trait. Varieties that are self-fertile, are characterized by high yields, they do not have periodicity of fruiting, to a lesser extent, the ovaries fall off, and, most importantly, they do not depend on pollination by insects [10-12]. The introduction of such varieties into production would provide a stable yield over the years, less dependence on unfavorable weather conditions during flowering $[13,14]$. 
Pollination increases the yield of most types of agricultural crops, including pears. With good pollination of pear flowers, for each developed seed, the weight of the fruit increases from 3 to $5 \%$, and the shape of the fruit becomes more regular [15]. It is necessary to select at least two varieties of pollinators for self-infertile varieties. This eliminates the danger of poor pollination, when one pollinator, for some reason, does not bloom. Pollination with a mixture of pollen of 2-3 varieties increases setting, improves retention of fruits on the tree. In this regard, the study of the degree of self-fertility and inter-pollination of new varieties in each fruit zone is necessary, which was the purpose of our research.

The main breeding studies were carried out according to generally accepted programs and methods, both in the pear variety study garden, in the Krasnodar, and in the laboratories for the variety study and selection of horticultural crops NCFSCHVW.

The objects of the study were 20 promising pear varieties (Pyrus communis L) of various ecological and geographical groups, differing in terms of ripening. The work was carried out in the conditions of the Kuban zone in the garden of variety study 2otd. OPH "Central" (Krasnodar); trees planted in 2007, a plot without irrigation.

To determine self-fertility and identify the best pollinators, the work was carried out according to three options:

1- option - self-pollination without applying pollen (b / o);

2- option - pollination with artificial application pollen of the same variety and pollinator varieties;

3 - option - free pollination (control).

The counts of the ovary from natural and artificial pollination were carried out 3 times: 1 st in 15 days after the end of flowering; 2nd ovary after June shedding; 3rd before harvest. The pollination results were determined by the ratio of the number of pollinated flowers and fruit set. According to the second revision, a cultivar was considered a good pollinator, the pollen of which, when pollinated, ensured the setting of a number of fruits higher than that of the control, equal to or close to it. Free pollination was used as a control. The cultivars that provided fruit setting of at least $60-70 \%$ in relation to the control were assigned to the group of acceptable pollinators. Cultivars whose pollen produced a fruit set rate of less than $50 \%$ relative to controls were considered unacceptable pollinators.

Data on the study of self-fertility of new varieties and hybrids of pears are presented in table 1 , from which it follows that most of the varieties are practically not self-infertile. With cross-pollination, not all pollinating varieties had a high fertilization efficiency. Crosspollinated varieties had a rather narrow selectivity for pollinating varieties, which, moreover, varied from year to year.

As a result of the research, it was established that the Originalnaya variety is self-infertile, since both when pollinated with its pollen and without pollination, its percentage of setting is equal to 0 . In this regard, it definitely needs pollinating varieties. Varieties: Starkrimson, Bere Morettini and Williams, when pollinated by Originalnaya for three years, showed a percentage of fruit set higher than control $(196,136.7,129.5$, respectively) and are considered the best pollinators for this variety (table 1).

It was determined that the Ladozhskaya variety is not at all suitable as a pollinator for the Originalnaya variety, but the Originalnaya variety is a good pollinator for the Ladozhskaya variety.

The best pollinators for the Talgarskaya krasavitsa variety were Clapp's Favorite and Conference, the percentage of pollination was 71.8 and 87.2, respectively. The following varieties can be considered good: Krasnodar summer and Kubanskaya late, in which the percentage of fruit setting is higher than $50 \%$ compared to the control. The varieties Bere Napoleon and Starkrimson turned out to be unacceptable pollinators, with the percentage of setting below 50. The Talgarskaya krasavitsa variety, when pollinated with its own pollen, showed partial self-fertility $-7.2 \%$, but without pollination -0 , which suggests that when 
setting this variety, it is still necessary take into account the presence of a pollinator variety. It is noted that with self-pollination, the obtained fruits are somewhat smaller in size and the number of seeds in the fruits is less and they are puny.

Table 1. Selection of pollinator varieties for promising pear varieties

\begin{tabular}{|c|c|c|c|c|c|c|c|c|}
\hline \multirow[t]{2}{*}{ Hybrid family } & \multicolumn{2}{|c|}{2018} & \multicolumn{2}{|c|}{2019} & \multicolumn{2}{|c|}{2020} & \multicolumn{2}{|c|}{ average $\%$} \\
\hline & 1 & 2 & 1 & 2 & 1 & 2 & 1 & 2 \\
\hline \multicolumn{9}{|l|}{ Originalnaya } \\
\hline $\mathrm{x}$ Bere Morettini & 2.5 & 100 & 1.3 & 68.4 & 2.9 & 241.6 & 2.2 & 136.7 \\
\hline x Starkrimson & 2.8 & 112 & 3.6 & 184.5 & 3.5 & 291.6 & 3.3 & 196.0 \\
\hline $\mathrm{x}$ Williams & 3.7 & 148 & 1.4 & 73.7 & 2.0 & 166.7 & 2.4 & 129.5 \\
\hline x Ladozhskaya & 0 & - & 0 & - & 0 & - & 0 & - \\
\hline $\mathrm{x}$ Originalnaya & 0 & - & 0 & - & 0 & - & 0 & - \\
\hline no pollination & 0 & - & 0 & - & 0 & - & 0 & - \\
\hline control & 2.5 & 100 & 1.9 & 100 & 1.2 & 100 & 1.9 & 100 \\
\hline \multicolumn{9}{|l|}{ Talgarskaya krasavitsa } \\
\hline x Clapp's Favorite & 5.3 & 82.8 & 5.9 & 77.6 & 5.5 & 59.1 & 5.6 & 73.2 \\
\hline $\mathrm{x}$ Bere Napoleon & 2.4 & 37.5 & 4.1 & 53.9 & 4.2 & 45.2 & 3.6 & 45.5 \\
\hline x Starkrimson & 2.8 & 43.7 & 4.2 & 55.2 & 3.3 & 35.5 & 3.4 & 44.8 \\
\hline $\begin{array}{l}\text { x Krasnodarskaya } \\
\text { letnyaya }\end{array}$ & 7.0 & 109.7 & 1.8 & 23.7 & 4.0 & 43.0 & 4.3 & 58.8 \\
\hline $\begin{array}{l}\text { x Kubanskaya } \\
\text { pozdnyaya }\end{array}$ & 2.4 & 37.5 & 4.2 & 55.2 & 6.7 & 70.0 & 4.4 & 54.2 \\
\hline $\mathrm{x}$ Conference & 5.0 & 78.1 & 6.3 & 82.9 & 9.0 & 96.8 & 6.8 & 85.9 \\
\hline $\begin{array}{l}\text { x Talgarskaya } \\
\text { krasavitsa }\end{array}$ & 1.1 & 17.2 & 0 & - & 0.4 & 4.3 & 0.5 & 7.2 \\
\hline no pollination & 0 & - & 0 & - & 0 & - & 0 & - \\
\hline control & 6.4 & 100 & 7.6 & 100 & 9.3 & 100 & 7.8 & 100 \\
\hline \multicolumn{9}{|l|}{ Shikhan } \\
\hline $\mathrm{x}$ Leven & 4.2 & 20.8 & 4.3 & 113.1 & 2.9 & 161.1 & 3.8 & 98.3 \\
\hline x Zimnyaya Mlievskaya & 6.8 & 33.7 & 3.1 & 81.6 & 1.2 & 66.7 & 3.7 & 60.7 \\
\hline $\begin{array}{l}\text { x Kubanskaya } \\
\text { pozdnyaya }\end{array}$ & 1.6 & 7.9 & 3.1 & 81.6 & 2.0 & 111.1 & 2.2 & 66.8 \\
\hline $\mathrm{x}$ Bere Ardanpon & 2.2 & 10.9 & 3.5 & 92.1 & 1.6 & 88.9 & 2.4 & 64.0 \\
\hline $\begin{array}{l}\text { x Williams Rouge } \\
\text { Delbara }\end{array}$ & 16.9 & 83.7 & 2.4 & 63.1 & 2.4 & 133.3 & 7.2 & 93.4 \\
\hline $\mathrm{x}$ Colette & 11.8 & 58.4 & 3.7 & 97.4 & 1.0 & 55.5 & 5.5 & 70.4 \\
\hline x Shikhan & 0 & - & 0 & - & 0 & - & 0 & - \\
\hline no pollination & 0 & - & 0 & - & 0 & - & 0 & - \\
\hline control & 20.2 & 100 & 3.8 & 100 & 1.8 & 100 & 8.6 & 100 \\
\hline \multicolumn{9}{|l|}{ Malyshka } \\
\hline $\mathrm{x}$ Starkrimson & 0.9 & 6.7 & 1.3 & 6.25 & 0.8 & 8.5 & 1.0 & 6.8 \\
\hline x Clapp's Favorite & 0.9 & 6.7 & 2.4 & 11.5 & 0.9 & 9.6 & 1.4 & 9.6 \\
\hline x Ladozhskaya & 0 & - & 0 & - & 0 & - & 0 & - \\
\hline x Malyshka & 6.7 & 49.6 & 4.3 & 20.7 & 4.3 & 45.7 & 5.1 & 34.9 \\
\hline no pollination & 0 & - & 0 & - & 0.5 & 5.3 & 0.2 & 1.4 \\
\hline control & 13.5 & 100 & 20.8 & 100 & 9.4 & 100 & 14.6 & 100 \\
\hline \multicolumn{9}{|l|}{ Ladozhskaya } \\
\hline x Clapp's Favorite & 0.8 & 19.0 & 1.1 & 68.8 & 2.1 & 20.2 & 1.3 & 24.0 \\
\hline
\end{tabular}




\begin{tabular}{|c|c|c|c|c|c|c|c|c|}
\hline $\mathrm{x}$ Williams & 3.1 & 73.8 & 1.8 & 112.5 & 2.7 & 26.0 & 2.5 & 46.3 \\
\hline x Malyshka & 4.4 & 104.8 & 1.0 & 62.5 & 5.5 & 52.9 & 3.6 & 66.7 \\
\hline x Krasnobokaya & 1.7 & 40.5 & 1.2 & 75.0 & 2.2 & 21.2 & 1.7 & 31.5 \\
\hline $\mathrm{x}$ Originalnaya & 2.7 & 60.0 & 2.7 & 168.7 & 4.9 & 47.1 & 3.4 & 62.9 \\
\hline x Ladozhskaya & 2.8 & 66.7 & 0.3 & 18.7 & 0.3 & 2.9 & 1.1 & 20.4 \\
\hline no pollination & 0 & - & 0.4 & 25.0 & 0.4 & 3.8 & 0.4 & 7.4 \\
\hline control & 4.2 & 100 & 1.6 & 100 & 10.4 & 100 & 5.4 & 100 \\
\hline \multicolumn{9}{|l|}{ Iyulskaya rannyaya } \\
\hline x Mramornaya & 11.2 & 107.7 & 7.3 & 83.9 & 6.3 & 64.9 & 8.3 & 84.5 \\
\hline $\begin{array}{l}\text { x Kubanskaya } \\
\text { Sochnaya }\end{array}$ & 1.1 & 10.6 & 6.2 & 71.3 & 4.6 & 47.4 & 4.0 & 41.7 \\
\hline x Ladozhskaya & 4.8 & 46.1 & 6.3 & 72.4 & 7.1 & 73.2 & 6.1 & 63.5 \\
\hline x Williams & 4.1 & 39.4 & 5.6 & 64.4 & 4.4 & 45.4 & 4.7 & 49.0 \\
\hline x Iyulskaya rannyaya & 3.6 & 34.6 & 3.7 & 42.5 & 2.1 & 21.6 & 3.1 & 32.3 \\
\hline no pollination & 4.0 & 38.5 & 0 & - & 4.0 & 41.2 & 2.7 & 28.1 \\
\hline control & 10.4 & 100 & 8.7 & 100 & 9.7 & 100 & 9.6 & 100 \\
\hline \multicolumn{9}{|l|}{ Elite 4-11-90 } \\
\hline x Williams & 1.4 & 63.6 & 2.1 & 161.5 & 3.3 & 78.6 & 2.3 & 88.5 \\
\hline x Starkrimson & 2.4 & 109.1 & 2.2 & 169.2 & 0.7 & 16.7 & 1.8 & 69.2 \\
\hline x Clapp's Favorite & 1.5 & 68.2 & 3.4 & 261.5 & 1.8 & 42.8 & 2.2 & 84.6 \\
\hline x Iyulskaya rannyaya & 2.1 & 95.4 & 0.5 & 38.5 & 3.2 & 76.2 & 1.9 & 73.1 \\
\hline $\mathrm{x}$ elite $4-11-90$ & 0 & - & 0 & - & 0 & - & 0 & - \\
\hline no pollination & 0 & - & 0 & - & 0 & - & 0 & - \\
\hline control & 2.2 & 100 & 1.3 & 100 & 4.2 & 100 & 2.6 & 100 \\
\hline
\end{tabular}

Note: $1-\%$ of set fruits to pollinated flowers; $2-\%$ to control

The winter variety Shikhan is self-fertile, since it does not set fruit at all when pollinated with its own pollen. The best pollinators for him from the tested varieties are the winter variety Leuven and the late summer variety Williams Rouge Delbara with the percentage of setting close to the control: 98.3 and $93.4 \%$. Winter varieties can be considered acceptable pollinators: Bere Ardanpon, Zimnyaya Mlievskaya and Kubanskaya pozdnyaya.

The early summer variety Malyshka is very productive. With free pollination, it has a high percentage of fruit setting, on average over three years it is 14.6. The variety itself can be considered partially self-fertile; when pollinated with its own pollen, a high $-34.9 \%$ percentage of setting in three years is noted, but without pollination, $\%$ of fruit setting over the years of research is 0.2 . There was no better pollinator for him from the selected varieties. Research needs to continue.

Ladozhskaya is summer ripening variety, partially self-fertile. The percentage of pollination with its own pollen is 20.4 , and without pollination $-7.4 \%$. The best pollinator among the selected varieties was not, the following varieties can be considered acceptable: Malyshka and Originalnaya.

Iyulskaya rannyaya variety has a high percentage of fruit setting when pollinated with its own pollen, 32.3 and $28.1 \%$, and it indicates that it is self-fertile variety. The best pollinator for him is the Mramornaya variety - $84.5 \%$, the permissible - Ladozhskaya, $63.5 \%$.

The elite form 4-11-90 does not set fruit at all from self-pollination. She is self-infertile. The best pollinators for her are the varieties: Williams, Clapp's Favorite and Iyulskaya rannyaya with the percentage of setting close to the control $(88.5 ; 84.6$ and 73.1 , respectively), permissible - variety Starkrimson, 69.2\%.

As a result of studies on the self-fertility of pears, it was established that most of the varieties not self-infertile. These are the varieties: Original, Shihan, elite form 4-11-90. 
The varieties Ladozhskaya, Malyshka and Talgarskaya krasavitsa showed partial selffertility, which does not always repeat over the years and with a very low percentage of fruit setting. In some years these varieties bear fruit upon self-pollination, but in such a small amount (from 0.2 to $5 \%$ ) that practically self-pollination does not provide even a weak harvest.

A self-fertile cultivar Iyulskaya rannyaya was identified, which, upon self-pollination for three years, set fruits at a level close to the control.

The best pollinating cultivars for promising pear cultivars were identified: Originalnaya, Talgarskaya krasavitsa, Shikhan and elite form 4-11-90.

To obtain high yields, all pear varieties need cross-pollination using the best pollinators.

It was noted that artificial pollination in varieties that were good pollinators was significantly higher than free pollination.

\section{References}

1. M. Quinet, S. Kelecom, O. Raspé., A. L. Jacquemart, Sci. Horticulturae, 165, 1-4 (2014) https://doi.org/10.1016/j.scienta.2013.10.023

2. M. Quinet, A.L. Jacquemart. Eur. J. Agron.,. 91, 84-92 (2017) http://dx.doi.org/10.1016/j.eja.2017.09.015

3. H. Claessen, W. Keulemans, B. Van de Poel, N. De Storme, Front. Plant Sci., 10, 407 (2019) https://doi.org/10.3389/fpls.2019.00407

4. P. De Franceschi, L. Dondini, J.Sanzol, J. Exp. Bot., 63(11), 4015-4032 (2012) https://doi.org/10.1093/jxb/ers108

5. M. Bagheri, A Ershadi, Biocatal. Agric. Biotechnol., 27, 101672 (2020) https://doi.org/10.1016/j.bcab.2020.101672

6. H.T. Kim, A.H.K. Robin, I. S. Nou, Plant Breed. Biotechnol., 4(2), 198-211 (2016) https://doi.org/10.9787/PBB.2016.4.2.198

7. S. L. Shi, H. Y. Cheng, L. Wu, Z. H. Xie, C. Gu, S. L. Zhang, Sci. Hortic., 238, 350-355 (2018) https://doi.org/10.1016/j.scienta.2018.05.003

8. S. Bennici, M. Di Guardo, G. Distefano, G. Las Casas, F. Ferlito, P. De Franceschi, L. Dondini, A. Gentile, S. La Malfa, Forests, 11(11), 1228 (2020) https://doi.org/10.3390/f11111228

9. F. Gasi, O. Frøynes, B. Kalamujić Stroil, L. Lasi, N. Pojskić, M. Fotirić Akšić, M. Meland, Agronomy, 10(9), 1372 (2020) https://doi.org/10.3390/agronomy1009137210

10. B. Geslin, M.A. Aizen, N. Garcia, A. Pereira, E. Vaissière, L.A. Garibaldi, Agric. Ecosyst. Environ., 248, 153-161 (2017) https://doi.org/10.1016/j.agee.2017.07.035

11. P.L. Hunicken, C.L. Morales, N. Garcia, L.A. Garibaldi, Neotrop. Entomol., 49, 525-532 (2020) https://doi.org/10.1007/s13744-020-00763-0

12. A. Zisovich, A. Raz, R. Stern, M. Goldway, Acta Hortic., 967, 181-190 (2011) In https://doi.org/10.17660/ActaHortic.2012.967.21

13. A. Gharehaghaji, K. Arzani, H. Abdollahi, A. Shojaeiyan, L Dondini, P. De Franceschi, Tree Gen. Genom., 10(2), $411-428$ (2014) https://doi.org/10.1007/s11295-013-0696-7

14. S. Lautenbach, R. Seppelt, J. Liebscher, C.F. Dormann, PLoS ONE, 7(4), e35954 (2012) https://doi.org/10.1371/journal.pone.0035954

15. L.A. Garibaldi, A.M. Aizen, M.A. Klein, A.S. Cunningham, L.D. Harder, Proceed. Nat. Acad. Sci., 108(14), 5909-5914 (2011) https://doi.org/10.1073/pnas.1012431108 